\title{
Manageable risk factors associated with bacterial and coliform counts in unpasteurized bulk milk in Flemish dairy herds
}

\author{
S. Piepers, ${ }^{* 1}$ P. Zrimšek,† P. Passchyn, ${ }^{*} \ddagger$ and S. De Vliegher ${ }^{*}$ \\ ${ }^{*}$ M-team \& Mastitis and Milk Quality Research Unit, Department of Reproduction, Obstetrics and Herd Health Faculty of Veterinary Medicine, \\ Ghent University, 9820 Merelbeke, Belgium \\ †Clinic for Reproduction and Horses, Veterinary Faculty, University of Ljubljana, 1000 Ljubljana, Slovenia \\ ‡Milk@vice, 8820 Torhout, Belgium
}

\section{ABSTRACT}

Associations between herd management practices and both bacterial counts (BC) and coliform counts (CC) from 254 and 242 dairy herds in Flanders (Belgium), respectively, were studied. Data were analyzed using multivariable, multilevel linear regression analysis, allowing variance components analyses. Both $\mathrm{BC}$ and $\mathrm{CC}$ fluctuated throughout the year, although the milk quality parameters followed an opposite pattern. Bacterial count values decreased with each increase of the cleaning frequency of the cubicles (once per week, once per day, twice per day, or more than twice per day) between January and March. Herds with a conventional milking parlor had substantially lower BC than herds where the cows were milked using an automatic milking system. Lower BC were observed when the milking parlor was equipped with an automatic cluster removal system, when premilking teat disinfection was applied, when the dry cows were supplemented with a mix of minerals and vitamins, and when the teats were prepared either first wet and dried or via an automatic milking system. Milking cows with a high-pipeline milking parlor setup or with an automatic milking system was associated with substantially higher CC values. Herds where prepartum heifers were often treated with antimicrobials before calving had a lower CC than farms where heifers were either not or only rarely treated. Most variation in $\mathrm{BC}$ and $\mathrm{CC}$ resided at the herd level rather than at the observation level, indicating that management is important in the control of both BC and CC. Still, only a small proportion of the total variance was explained by factors capturing information related to the milking, herd health, and dry cow management, which suggests that the bacteriological milk quality and, in particular, $\mathrm{CC}$ is primarily driven by other factors than the ones included in this study.

Key words: bacterial count, bulk milk, coliform count, dairy herd, management practice

Received June 30, 2013.

Accepted February 24, 2014.

${ }^{1}$ Corresponding author: Sofie.Piepers@UGent.be

\section{INTRODUCTION}

High bacterial levels in milk, whether originating from the cow or the environment, substantially affect the quality, safety, and consumer acceptance of milk and dairy-derived products. Some bacteria found in unpasteurized milk such as Staphylococcus aureus, Escherichia coli, Listeria monocytogenes, Campylobacter jejuni, Mycobacterium tuberculosis, and Salmonella spp. pose a potential risk for human health (Gilmour and Rowe, 1990; Murphy and Boor, 2000). Bacteria that are not known to be pathogenic can cause flavor changes, rancidity, and thus reduced shelf life (Boor, 2001; Barbano et al., 2006). Bacterial quality of milk can be determined using several parameters including bacterial counts (BC), preliminary incubation counts, laboratory pasteurization counts, and coliform counts (CC; Murphy, 1997). Among these, BC is the most commonly used one in regulatory programs (Murphy and Boor, 2000) and estimate the number of colonyforming units or individual BC (IBC) present in unpasteurized bulk tank milk.

In Flanders (Belgium), the official mandatory milkquality regulations follow European legislation and require a geometric mean $\mathrm{BC}$ over the last 2 mo (based on 2 recordings per month) $<100 \times 10^{3} \mathrm{IBC} / \mathrm{mL}$ of milk. In contrast, testing of $\mathrm{CC}$ is nonobligatory for milk quality in Flanders, yet implemented as part of an incentive program. Similar to other countries, such as Ireland (Berry et al., 2006) and different regions in the United States (Jayarao et al., 2004), the majority of milk processors in Flanders pay incentives of up to $€ 0.75 / 100 \mathrm{~L}$ of milk to farmers that meet higher quality requirements, including geometric mean bacterial counts $<50 \times 10^{3} \mathrm{IBC} / \mathrm{mL}$ and geometric mean $\mathrm{CC}$ $<50 \mathrm{cfu} / \mathrm{mL}$ over the last $2 \mathrm{mo}$ (4 recordings) in combination with a geometric mean SCC $<350 \times 10^{3}$ cells/ $\mathrm{mL}$, in the absence of antibiotic residues in any milk delivery, all to ensure the image of milk as a high-quality and safe product. Although bulk tank $\mathrm{BC}$ and $\mathrm{CC}$ in Flanders decreased by $19.2 \%$ between 2005 and 2008, an increase of almost $10 \%$ was observed between 2008 and 2009 (K. Lommelen, Milk Control Centre, Lier, 
Belgium, personal communication), warranting the need to understand the reasons behind this tendency.

Most studies have identified factors holding information on milking and equipment hygiene, sanitizing procedures (Elmoslemany et al., 2009a,b; Pantoja et al., 2011), and milk storage conditions (Murphy and Boor, 2000), explaining variability in BC and CC. Apart from 2 studies, of which one was conducted in Chile (van Schaik et al., 2005) and the other in Canada (Elmoslemany et al., 2010), factors related to either herd health management, transition and feeding management, or housing, which are known to affect udder health, have not been studied as potential risk factors. Still, mastitiscausing streptococci such as Streptococcus uberis and Streptococcus agalactiae can be important contributors to bacterial levels of unpasteurized bulk tank milk (Zadoks et al., 2004). Given this information, one could anticipate that the latter management practices are also relevant for milk quality and $\mathrm{BC}$ in particular, and could explain the increase in $\mathrm{BC}$ and $\mathrm{CC}$ in Flanders, coincident with the increase in the average bulk milk SCC (BMSCC) during the same period.

The main objective of this study was to evaluate to what extent differences in management practices different from those related to milking and equipment hygiene are associated with $\mathrm{BC}$ and $\mathrm{CC}$ in unpasteurized bulk milk on Flemish dairy herds. A secondary objective was to assess whether the variation in $\mathrm{BC}$ and $\mathrm{CC}$ resided mostly at the herd or at the observation level.

\section{MATERIALS AND METHODS}

\section{Herd Demographic Data}

In 2009, Flanders had 6,971 dairy herds, with an average herd size and milk production of 40.9 cows and 8,059 milk $\mathrm{kg} / \mathrm{cow}$ per year. The average milk quota size was $310,708 \mathrm{~kg}$. Herds included in this study were, on average, larger (65.8 cows/herd) in both size and milk production $(8,503 \mathrm{~kg}$ of milk/cow per year). The average of the geometric mean of $\mathrm{BC}$ and $\mathrm{CC}$ in Flanders was $11.3 \times 10^{3} \mathrm{IBC} / \mathrm{mL}$ and $10 \mathrm{cfu} / \mathrm{mL}$, respectively. In $2009,97 \%$ of the herds met the requirements for BC according to the European legislation (geometric mean $\mathrm{BC}<100 \times 10^{3} \mathrm{IBC} / \mathrm{mL}$ ), whereas approximately $85 \%$ of the herds met the specific requirements for higher-quality milk for $\mathrm{CC}$ (geometric mean $\mathrm{CC}<50$ $\mathrm{cfu} / \mathrm{mL}$ ). The average of the geometric mean BMSCC was 230,000 cells $/ \mathrm{mL}$. The milk quality of the herds included in this study was comparable.

\section{Herd Selection and Data Collection}

A written web-based questionnaire was conducted between January 2010 and July 2010. The questionnaire was pretested and fine-tuned in close cooperation with 4 dairy farmers before the start of the study.

In total, 254 farmers completed the online questionnaire that consisted of 39 questions concerning general management $(\mathrm{n}=8)$, herd health management $(\mathrm{n}=$ $5)$, milking management $(\mathrm{n}=11)$, calving $(\mathrm{n}=3)$ and dry cow management $(\mathrm{n}=6)$, and nutrition $(\mathrm{n}=6)$ in place on farm during 2009 (Table 1).

From all farms that completed the online questionnaire, the bulk tank milk $\mathrm{BC}$ and $\mathrm{CC}$ records measured at 2-wk intervals from January 2009 to December 2010 were retrieved from the Milk Control Centre Flanders that executes the (regulatory) farm screening program in Flanders, Belgium. Bacterial counts and $\mathrm{CC}$ were examined on unpasteurized bulk milk samples collected in 30-mL sterile screw-cap tubes by trained milk haulers. The samples were kept cooled $\left( \pm 4^{\circ} \mathrm{C}\right)$ until arrival at the laboratory.

\section{Total BC and CC}

All microbiological analyses were performed within $24 \mathrm{~h}$ after pick up at the farm. The milk samples were

Table 1. Overview of all herd management practices collected via a web-based questionnaire on 254 dairy herds in Belgium

\begin{tabular}{|c|c|}
\hline Management type & Description \\
\hline Herd health management & $\begin{array}{l}\text { Registration of animal diseases, herd health monitoring by veterinarian, monthly incidence of clinical } \\
\text { mastitis, antimicrobial treatment during lactation of subclinical mastitis, treatment of prepartum heifers with } \\
\text { antimicrobials }\end{array}$ \\
\hline Milking management & $\begin{array}{l}\text { Milking machine type, milking parlor type, cows kept in headlock after milking, use of automatic cluster } \\
\text { removal, providing a preparation lag time of } 60 \mathrm{~s} \text {, teat-preparation method, application of premilking teat } \\
\text { disinfection, application of postmilking teat disinfection, machine unit liner, rinsing of machine unit liners, } \\
\text { replacement of machine unit liners }\end{array}$ \\
\hline Calving management & Calving on pasture, presence of calving pen, use of calving pen for sick cows \\
\hline Nutrition management & $\begin{array}{l}\text { Concentrate provided during milking, concentrate provided on top of forage, concentrate provided via TMR, } \\
\text { concentrate provided via automatic feeder, forage provided, type of forage feeding system }\end{array}$ \\
\hline Dry cow management & $\begin{array}{l}\text { Drying-off procedure, use of long-acting antimicrobials, adapted diet provided, mineral/vitamin mix provided, } \\
\text { use of external teat sealer, use of internal teat sealer }\end{array}$ \\
\hline
\end{tabular}


vortexed before the start of the analyses. For BC, undiluted milk samples were used and automatically analyzed by means of a BactoScan FC (Foss Electric A/S, Hillerød, Denmark). Bacterial counts were expressed as the number of IBC $/ \mathrm{mL}$ of milk. For CC, milk samples were first diluted using tryptone salt broth at 1:10. One milliliter of diluted milk was plated on 3M Petrifilm CC plates (3M, St. Paul, MN) and incubated at $30^{\circ} \mathrm{C}$ for 24 h. Colony-forming units were counted electronically using an automated colony counter (protoCOL; Synbiosis, Cambridge, UK). Coliform counts were expressed as the number of colony-forming units per milliliter of milk. Per month, a geometric mean $\mathrm{BC}$ and $\mathrm{CC}$ was calculated based on the last 4 recordings (last $2 \mathrm{mo}$ ). A logarithmic transformation of the geometric mean BC and $\mathrm{CC}$ was performed to normalize the data before statistical analyses.

\section{Statistical Analysis}

All data were entered in an electronic spreadsheet program (Excel 2010; Microsoft Corp., Redmond, WA) and were checked for unlikely values. Monthly geometric means for $\mathrm{BC}(\mathrm{n}=3046)$ and $\mathrm{CC}(\mathrm{n}=2895)$ were available for 254 and 242 of the farms, respectively.

The regression model-building process to identify management practices associated with $\mathrm{BC}$ and $\mathrm{CC}$ involved several steps as described previously (De Vliegher et al., 2004) and is presented in a flowchart (Figure 1). Linear mixed regression models with BC and $\mathrm{CC}$ as dependent variables were fit using SPSS software (version 17.0; SPSS Inc., Chicago, IL). In all models, herd was included as random effect to model the repeated measurements within herds using a firstorder autoregressive correlation structure.

Initially, unconditional associations were tested between the continuous dependent variables at the herd level (logarithm of $\mathrm{BC}$ and logarithm of CC, respectively) and all management practices $(\mathrm{n}=39$; Table 1$)$ and month of observation as fixed effects, the latter to take into account the longitudinal nature of the data. Statistical significance at this step was assessed at $P \leq$ 0.20 (Maldonado and Greenland, 1993). Some of the categorical variables were recoded based on biological reasons because of low frequencies in 1 or more categories in this step. Second, Pearson and Spearman rank correlation coefficients were calculated among the significant independent variables to avoid multicollinearity in the next steps. If 2 management practices had a correlation coefficient $\geq 0.6$, only 1 was withheld for further analysis. In the third step, multivariable models were built with the remaining management variables as independent variables, with logarithm of $\mathrm{BC}$ and logarithm of $\mathrm{CC}$, respectively, as dependent variables
(Tables 2, 3, and 4). Nonsignificant variables were removed using backward elimination at $P \leq 0.05$. In both models, all first-order interactions among month of observation and the remaining variables in the multivariable model were tested and removed when nonsignificant (Wald test, $P>0.05$ ). The adequacy of the final model was tested by examining normal probability plots of residuals and plots of residuals versus predicted values to check whether the assumptions of normality and homogeneity of variance had been fulfilled. No patterns indicating heteroscedasticity were revealed.

To evaluate the proportion of variance occurring at the different levels of the data hierarchy, 2-level null models (intercept and month of observation as fixed effects only, to take into account the longitudinal nature

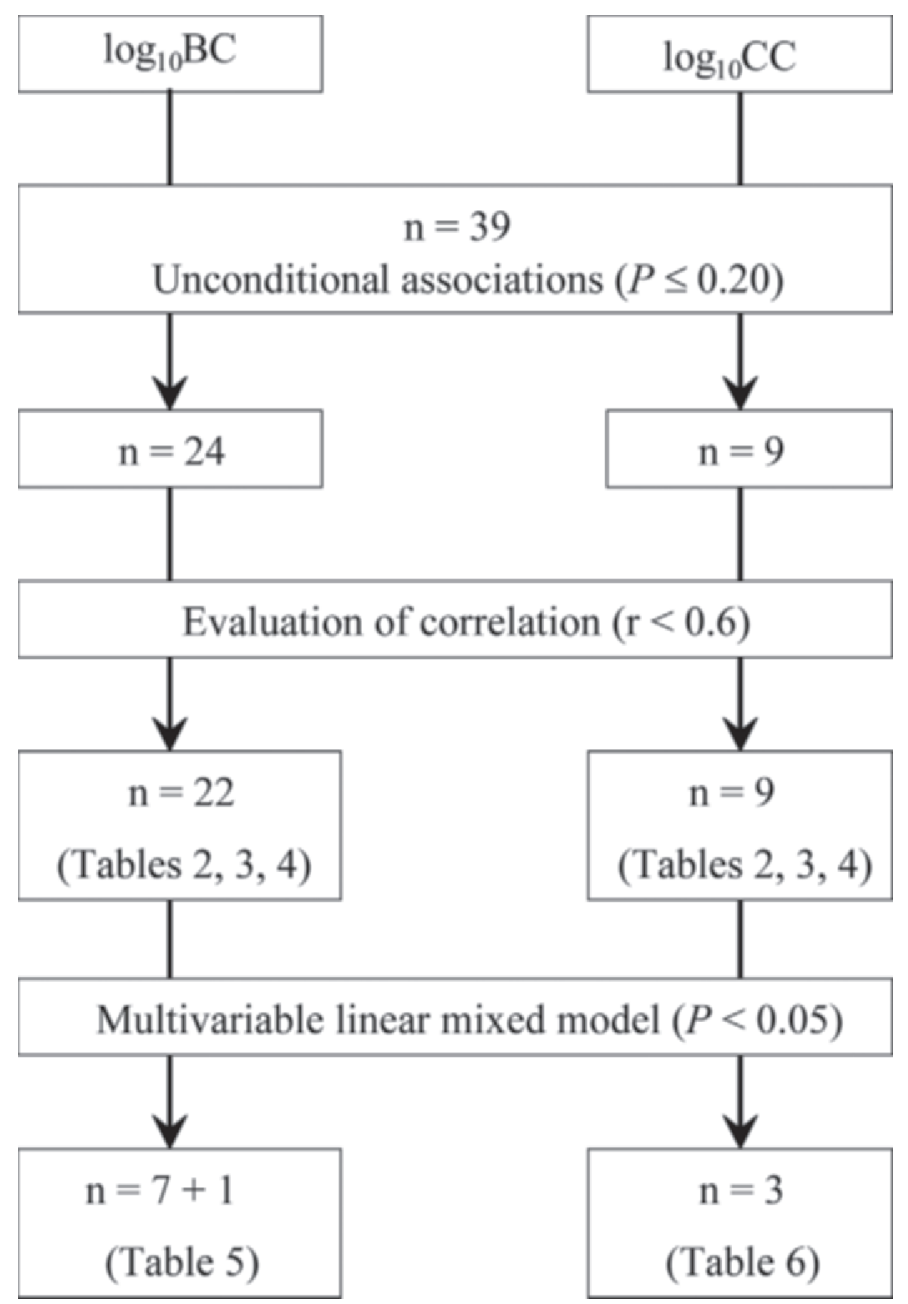

Figure 1. Flowchart of variable reduction through different steps in the statistical analysis. All univariable models were corrected for month of observation to take into account the longitudinal nature of the data. $\mathrm{BC}=$ bacterial count; $\mathrm{CC}=$ coliform count; $\mathrm{n}=7+1$ indicates interaction between month of observation and 1 other variable. 
Table 2. Unconditional associations between general and herd health management factors and logarithm of bacterial count (BC) and logarithm of coliform count $(\mathrm{CC})$ on 254 and 242 Flemish dairy farms, respectively $(P \leq 0.20)$

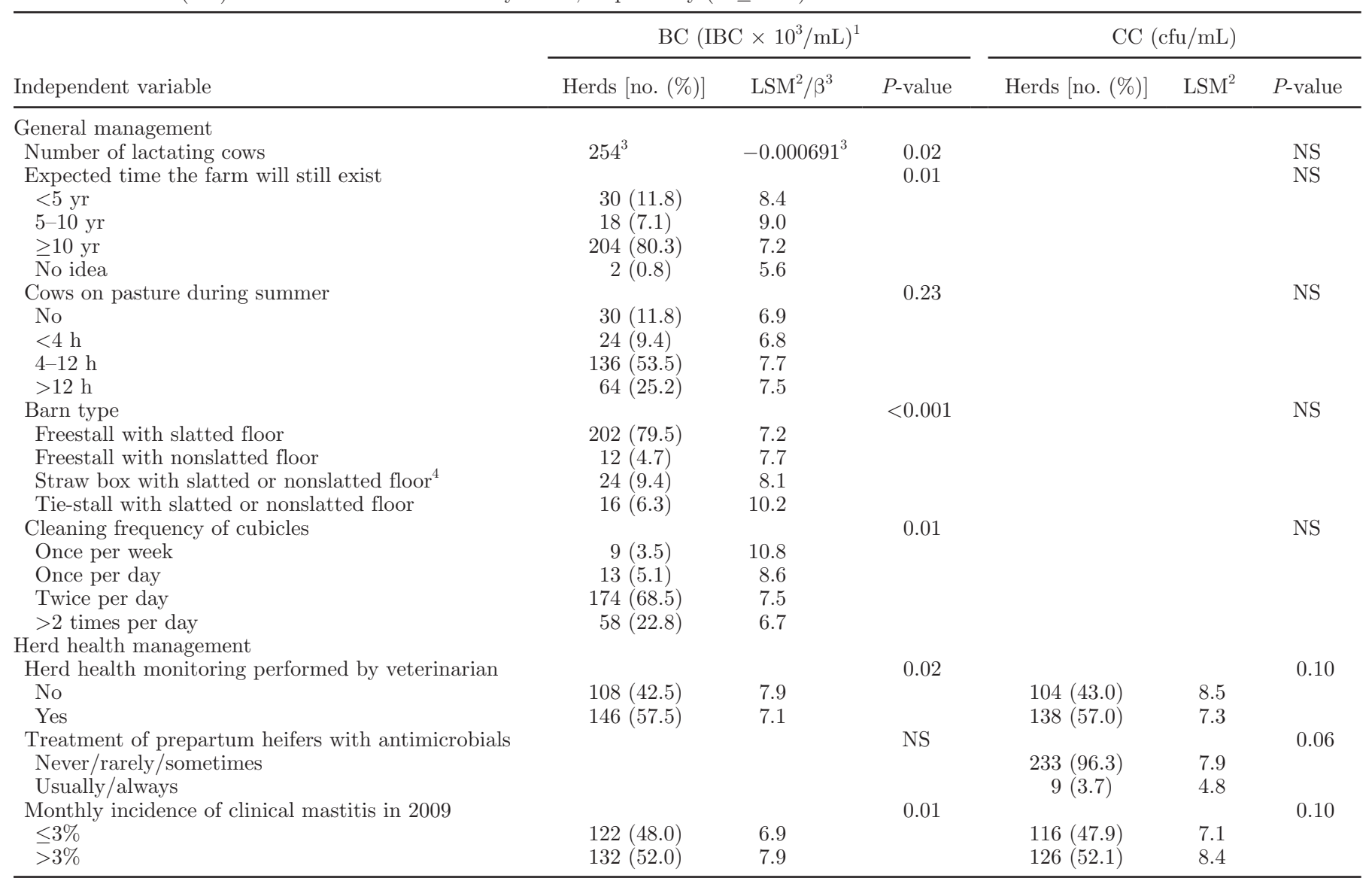

${ }^{1} \mathrm{IBC}=$ individual $\mathrm{BC}$.

${ }^{2}$ Back-transformed LSM of logarithm of $\mathrm{BC}\left(\times 10^{3} \mathrm{IBC} / \mathrm{mL}\right)$ or logarithm of $\mathrm{CC}(\mathrm{cfu} / \mathrm{mL})$, corrected for month of observation.

${ }^{3}$ Regression coefficient of the model.

${ }^{4}$ On 5 farms, the barn consisted of a straw box and some cubicles.

of the data), with herd as random effect were fit for both BC and CC.

\section{RESULTS}

\section{Descriptive Statistics}

The average herd size of the 254 herds included in the study was 65.8 [interquartile range (IQR) from 45 to 80] lactating cows per herd with an average milk quota size of $551,937 \mathrm{~kg}$ of milk (IQR from 375,750 to $676,500)$ per year. The average of the geometric mean $\mathrm{BC}$ was $9.1 \times 10^{3} \mathrm{IBC} / \mathrm{mL}\left(\mathrm{IQR}\right.$ from $5 \times 10^{3}$ to $11 \times$ $10^{3} \mathrm{cfu} / \mathrm{mL}$ ) and the average of the geometric mean CC was $21.3 \mathrm{cfu} / \mathrm{mL}$ (IQR from 2 to $16 \mathrm{cfu} / \mathrm{mL}$ ). Approximately $94 \%$ of the herds met the specific requirements for higher-quality milk in Belgium for $\mathrm{BC}$ (geometric mean $\mathrm{BC}<50 \times 10^{3} \mathrm{IBC} / \mathrm{mL}$ ), whereas $98.4 \%$ of the herds met the requirements according to the European legislation (geometric mean $\mathrm{BC}<100 \times 10^{3} \mathrm{IBC} / \mathrm{mL}$ ) for the whole year. However, $38.5 \%$ of the herds exceeded at least once in the studied years the specific requirements for higher-quality milk for CC (geometric mean $\mathrm{CC}<50 \mathrm{cfu} / \mathrm{mL}$ ). The average BMSCC was 223,621 cells/mL, with an IQR from 173,000 to 271,000 cells/ $\mathrm{mL}$. Similar figures were obtained using the subset of 242 farms of which monthly geometric mean CC values were available for further analyses.

Of the 254 herds, $60.2 \%(\mathrm{n}=153)$ only housed dairy cows, $22.9 \%(\mathrm{n}=58)$ also kept double-purpose or beef cows, and $16.9 \%(\mathrm{n}=43)$ also farmed other animals such as pigs. In almost $60 \%$ of the herds $(\mathrm{n}=146)$, some herd health aspects such as fertility, and (or) udder health, and (or) heifer rearing, and (or) claw health were monitored by a veterinarian on a regular basis. Disease registration was systematically done on approximately half of the herds. Almost $80 \%$ of the farms $(n=202)$ housed their cows in a freestall with slatted floor. 
Table 3. Unconditional associations between milking routine and logarithm of bacterial count (BC) and logarithm of coliform count (CC) on 254 and 242 Flemish dairy farms, respectively $(P \leq 0.20)$

\begin{tabular}{|c|c|c|c|c|c|c|}
\hline \multirow[b]{2}{*}{ Milking management } & \multicolumn{3}{|c|}{$\mathrm{BC}\left(\mathrm{IBC} \times 10^{3} / \mathrm{mL}\right)^{1}$} & \multicolumn{3}{|c|}{$\mathrm{CC}(\mathrm{cfu} / \mathrm{mL})$} \\
\hline & Herds [no. $(\%)]$ & $\mathrm{LSM}^{2}$ & $P$-value & Herds $[$ no. $(\%)]$ & $\mathrm{LSM}^{2}$ & $P$-value \\
\hline Low line & $189(74.4)$ & 7.2 & & $179(73.9)$ & 6.3 & \\
\hline High line & $24(9.4)$ & 10.0 & & $22(9.1)$ & 9.3 & \\
\hline With glass jars & $28(11.0)$ & 6.9 & & $28(11.6)$ & 5.6 & \\
\hline Automatic milking system & $13(5.1)$ & 7.7 & & $13(5.4)$ & 16.1 & \\
\hline Tandem & $53(20.9)$ & 8.1 & & $51(21.2)$ & 7.5 & \\
\hline Rotary & $19(7.5)$ & 6.8 & & $17(7.1)$ & 6.6 & \\
\hline Side-by-side & $6(2.4)$ & 7.2 & & $5(2.1)$ & 10.7 & \\
\hline Automatic milking system & $13(5.2)$ & 8.6 & & $13(5.4)$ & 17.0 & \\
\hline Tie-stall & $17(6.7)$ & 10.4 & & $16(6.6)$ & 7.9 & \\
\hline Cows kept in headlocks after milking & & & 0.17 & & & NS \\
\hline No, although possible & $150(59.1)$ & 7.5 & & & & \\
\hline Method of teat preparation & & & 0.01 & & & NS \\
\hline Wet and dry after/automatic & $42(16.5)$ & 7.0 & & & & \\
\hline Dry with paper towel & $155(61.0)$ & 7.9 & & & & \\
\hline Disinfection towels & $10(3.9)$ & 6.2 & & & & \\
\hline Dry with cloths & $47(18.5)$ & 7.8 & & & & \\
\hline Providing a preparation lag time of $60 \mathrm{~s}$ & & & $<0.001$ & & & 0.03 \\
\hline Never/rarely/sometimes & $94(37.0)$ & 8.2 & & $88(36.3)$ & 8.2 & \\
\hline Not applicable (rotary milking parlor) & $20(7.9)$ & 7.5 & & $19(7.9)$ & 12.2 & \\
\hline Always/usually/sometimes & $140(55.1)$ & 7.0 & & $135(55.8)$ & 7.1 & \\
\hline Application of premilking teat disinfection & & & 0.01 & & & NS \\
\hline Never/rarely/sometimes & $229(90.2)$ & 7.6 & & & & \\
\hline Always/usually & $25(9.8)$ & 6.0 & & & & NS \\
\hline Application of postmilking teat disinfection & & & 0.13 & & & \\
\hline Never/rarely/sometimes & $27(10.6)$ & 8.2 & & & & \\
\hline
\end{tabular}

\section{Unconditional Associations}

A first reduction based on unconditional associations and highly correlated variables revealed 22 and 9 herd management practices to be associated with logarithm of IBC and logarithm of $\mathrm{CC}$, respectively (Tables 2, 3 , and 4). A strong correlation was found between the number of cows, number of lactating cows, and milk quota size. The number of lactating cows was selected for further analysis.

\section{Final Multivariable, Multilevel Models}

The final multivariable, multilevel models for logarithm of $\mathrm{BC}$ and logarithm of $\mathrm{CC}$ are presented in Tables 5 and 6 , respectively. Although the correlation coefficient between type of milking machine and type of milking parlor did not exceed the cut-off value of 0.6 $(\mathrm{r}=0.27)$, a multivariable model for logarithm of $\mathrm{BC}$ in which both variables were included did not reach convergence, as all tie-stall milking parlors were obviously equipped with a high-pipeline setup (Table 7). Therefore, it was decided to exclude the variable type of milking machine from the multivariable model for logarithm of BC.

Factors Associated with BC. Individual BC varied throughout the year, with the highest values being observed from January to March and the lowest values from June to November $(P<0.001)$. Individual BC values decreased with each increase of the cleaning frequency of the cubicles (once per week, once per day, twice per day, or more than twice per day) between January and March (interaction between month of observation $\times$ cleaning frequency of cubicles, $P<0.05$; 
Table 4. Unconditional associations between nutrition, calving, and dry cow management and logarithm of bacterial count (BC) and logarithm of coliform count $(\mathrm{CC})$ on 254 and 242 Flemish dairy farms, respectively $(P \leq 0.20)$

\begin{tabular}{|c|c|c|c|c|c|c|}
\hline \multirow[b]{2}{*}{ Independent variable } & \multicolumn{3}{|c|}{$\mathrm{BC}\left(\mathrm{IBC} \times 10^{3} / \mathrm{mL}\right)^{1}$} & \multicolumn{3}{|c|}{$\mathrm{CC}(\mathrm{cfu} / \mathrm{mL})$} \\
\hline & Herds [no. (\%)] & $\mathrm{LSM}^{2}$ & $P$-value & Herds [no. (\%)] & $\mathrm{LSM}^{2}$ & $P$-value \\
\hline \multicolumn{7}{|l|}{ Nutrition management } \\
\hline Type of forage feeding system & & & $<0.001$ & & & NS \\
\hline Layers & $56(22.0)$ & 7.4 & & & & \\
\hline Partial mixed ration & $56(22.0)$ & 7.4 & & & & \\
\hline TMR & $131(51.6)$ & 7.1 & & & & \\
\hline No & $222(87.4)$ & 7.1 & & & & \\
\hline Yes & $32(12.6)$ & 9.9 & & & & \\
\hline Concentrate provided via automatic feeder & & & $<0.001$ & & & NS \\
\hline No & $81(31.9)$ & 8.4 & & & & \\
\hline Yes & $173(68.1)$ & 7.0 & & & & \\
\hline \multicolumn{7}{|l|}{ Dry cow management } \\
\hline Drying-off procedure & & & 0.11 & & & NS \\
\hline Mineral/vitamin mix provided & & & $<0.001$ & & & NS \\
\hline No & $67(26.4)$ & 9.1 & & & & \\
\hline Yes & $187(73.6)$ & 6.9 & & & & \\
\hline \multicolumn{7}{|l|}{ Calving management } \\
\hline Presence of calving pen & & & 0.01 & & & NS \\
\hline No (cows calve in tie-stall/cubicles) & $45(17.7)$ & 8.5 & & & & \\
\hline Yes & $209(82.3)$ & 7.2 & & & & \\
\hline Calving pen used for sick cows & & & 0.01 & & & NS \\
\hline No & $76(29.9)$ & 7.4 & & & & \\
\hline No, as there is no calving pen & $39(15.4)$ & 8.9 & & & & \\
\hline Yes & $139(54.7)$ & 7.1 & & & & \\
\hline
\end{tabular}

Figure 2). When cows were milked using an automated milking system, $\mathrm{BC}$ were higher than in other herds using different systems $(P<0.001)$. A lower BC was observed when the milking parlor was equipped with an automatic cluster removal system as opposed to when the milking clusters were removed manually $(P<$ 0.001). Lower BC was observed in herds where the teats were prepared either first wet and then dried or via an automatic milking system $(P<0.05)$. Premilking teat disinfection via dipping or spraying as well as supplementation of dry cows with minerals were associated with lower BC as well $(P<0.05)$.

Factors Associated with CC. Coliform counts varied throughout the year $(P<0.001$; Figure 3$)$. Herds with a high-line milking parlor setup or automatic milking system had substantially higher CC compared with herds using a low-line milking parlor setup or reservoir $(P<0.001)$. Farms that treated prepartum heifers with antimicrobials before calving had lower CC than farms where heifers were either not or only rarely treated before calving $(P<0.05)$.

\section{Variance Components}

When fitting null models, $93.6 \%$ of the variation in $\mathrm{BC}$ occurred at the herd level and $6.4 \%$ at the observation level, whereas for CC, 68.1 and $31.9 \%$ of the variation occurred at the herd and observation level, respectively, (Table 8). These proportions only changed slightly in the final multivariable models. Of the total variance in $\mathrm{BC}$ and $\mathrm{CC}$, only 4.6 and $2.1 \%$ of the variation, respectively, was explained by the fixed effects in the final models.

\section{DISCUSSION}

Several studies have identified risk factors associated with milk-quality parameters such as BC and CC (Elmoslemany et al., 2009a,b; Pantoja et al., 2011). Apart from 2 studies of which one was conducted in the 10th region of Chile (van Schaik et al., 2005) and another on Prince Edward Island in Canada (Elmoslemany et al., 2010), most studies have focused on factors associated 
Table 5. Final multivariable, multilevel model for logarithm of bacterial count (BC) of 254 Flemish dairy farms

\begin{tabular}{|c|c|c|c|c|}
\hline Independent variable & $\beta^{1}$ & SE & $\mathrm{LSM}^{2}$ & $P$-value ${ }^{3}$ \\
\hline Intercept & 1.20 & 0.079 & - & $<0.001$ \\
\hline Month of observation & & & & $<0.001$ \\
\hline January & Ref..$^{4}$ & - & 10.0 & \\
\hline February & 0.100 & 0.049 & 11.6 & 0.04 \\
\hline March & 0.016 & 0.065 & 11.3 & 0.80 \\
\hline April & -0.148 & 0.075 & 10.2 & 0.05 \\
\hline May & -0.197 & 0.082 & 9.2 & 0.02 \\
\hline June & -0.280 & 0.087 & 7.6 & 0.01 \\
\hline July & -0.367 & 0.090 & 6.8 & $<0.001$ \\
\hline August & -0.274 & 0.093 & 7.3 & 0.01 \\
\hline September & -0.216 & 0.094 & 7.4 & 0.02 \\
\hline October & -0.227 & 0.096 & 7.3 & 0.02 \\
\hline November & -0.200 & 0.097 & 7.8 & 0.04 \\
\hline December & -0.105 & 0.064 & 8.9 & 0.29 \\
\hline \multicolumn{5}{|l|}{ General management } \\
\hline Cleaning frequency of the housing & & & & 0.22 \\
\hline Once per week & Ref. & - & 10.1 & - \\
\hline Once per day & -0.114 & 0.094 & 8.2 & 0.22 \\
\hline Twice per day & -0.212 & 0.074 & 8.5 & 0.01 \\
\hline$>2$ times per day & -0.312 & 0.078 & 7.9 & 0.01 \\
\hline \multicolumn{5}{|l|}{ Milking management } \\
\hline Milking parlor type & & & & $<0.001$ \\
\hline Fishbone & Ref. & - & 7.6 & - \\
\hline Tandem & 0.056 & 0.022 & 8.6 & 0.01 \\
\hline Rotary & 0.003 & 0.034 & 7.6 & 0.92 \\
\hline Side-by-side & 0.063 & 0.059 & 8.7 & 0.28 \\
\hline Automatic milking system & 0.179 & 0.045 & 11.4 & $<0.001$ \\
\hline Tie-stall & 0.048 & 0.041 & 8.4 & 0.24 \\
\hline \multicolumn{4}{|l|}{ Use of automatic cluster removal } & $<0.001$ \\
\hline No & Ref. & - & 10.3 & — \\
\hline Yes & -0.148 & 0.029 & 7.3 & \\
\hline Teat preparation method & & & & 0.01 \\
\hline Wet and dry after/automatic & Ref. & - & 7.9 & - \\
\hline Dry with paper towel & 0.082 & 0.028 & 9.6 & 0.01 \\
\hline Disinfection towels & 0.037 & 0.052 & 8.7 & 0.47 \\
\hline Dry with cloths & 0.025 & 0.033 & 8.4 & 0.43 \\
\hline Application of premilking teat disinfection & & & & 0.01 \\
\hline Never/rarely/sometimes & Ref. & - & 9.3 & - \\
\hline Always/usually & -0.063 & 0.030 & 8.0 & 0.04 \\
\hline \multicolumn{5}{|l|}{ Dry cow management } \\
\hline Mineral/vitamin mix provided & & & & 0.01 \\
\hline No & Ref. & - & 9.2 & - \\
\hline Yes & -0.057 & 0.021 & 8.1 & \\
\hline Month of observation $\times$ cleaning frequency of barn $^{5}$ & & & & 0.01 \\
\hline
\end{tabular}

${ }^{1}$ Estimate.

${ }^{2}$ Back-transformed LSM of logarithm of $\mathrm{BC}\left[\times 10^{3}\right.$ individual $\left.\mathrm{BC}(\mathrm{IBC}) / \mathrm{mL}\right]$.

${ }^{3} P$-value of the fixed effects.

${ }^{4}$ Ref. $=$ reference.

${ }^{5}$ See Figure 2 for more detailed information.

with milking equipment and cow hygiene rather than on factors related to herd health in general. In the current study, several manageable risk factors associated with $\mathrm{BC}$ and $\mathrm{CC}$ that can be readily implemented by the Flemish dairy farmer to control $\mathrm{BC}$ and $\mathrm{CC}$ at acceptable levels were identified.

Web-based questionnaires are commonly used tools, as they allow for relatively easy and cheap data collection. This approach allowed us to include data of farms that were distributed over the 5 different Flemish prov- inces. The need to have internet access, however, might have selected the input of more contemporary farmers that are also better managers, potentially diminishing the external validity of the data (Dohoo et al., 2009). However, the high variation in BMSCC between the respondents suggests a wide diversity of management styles (Barkema et al., 1998). Also, both the average BMSCC and BC of the selected herds approached the average BMSCC and BC in 2009 for the whole of Flanders, being 230,000 cells $/ \mathrm{mL}$ and $11.3 \times 10^{3} \mathrm{IBC} / \mathrm{mL}$, 
Table 6. Final multivariable, multilevel model for logarithm of coliform count (CC) of 242 Flemish dairy farms

\begin{tabular}{lrrrc}
\hline Independent variable & $\beta^{1}$ & $\mathrm{SE}$ & LSM $^{2}$ & $P$-value \\
\hline Intercept & 0.694 & 0.039 & - & $<0.001$ \\
Month & & & & $<0.001$ \\
January & Ref. & & & \\
February & -0.020 & 0.028 & 4.7 & 0.47 \\
March & -0.043 & 0.036 & 4.5 & 0.01 \\
April & -0.007 & 0.042 & 4.9 & 0.24 \\
May & 0.026 & 0.045 & 5.3 & 0.86 \\
June & 0.073 & 0.047 & 5.9 & 0.11 \\
July & 0.232 & 0.048 & 8.4 & $<0.001$ \\
August & 0.309 & 0.049 & 10.1 & $<0.001$ \\
September & 0.260 & 0.050 & 9.0 & $<0.001$ \\
October & 0.213 & 0.051 & 8.1 & $<0.001$ \\
November & 0.201 & 0.051 & 7.9 & $<0.001$ \\
December & 0.137 & 0.051 & 6.8 & 0.01 \\
Milking management & & & & \\
Milking machine type & & & 5.7 & - \\
Low line & Ref. & - & 0.001 \\
High line & 0.171 & 0.076 & 9.6 & 0.03 \\
With glass jars & -0.064 & 0.069 & 4.9 & 0.35 \\
Automatic milking system & 0.419 & 0.098 & 13.8 & $<0.001$ \\
Herd health management & & & & \\
Treatment of prepartum heifers with antimicrobials & & & & 0.02 \\
Never/rarely/sometimes & Ref. & - & 8.7 & - \\
Usually/always & -0.261 & 0.115 & 4.9 & - \\
\hline
\end{tabular}

${ }^{1}$ Estimate.

${ }^{2}$ Back-transformed LSM of logarithm of CC ( $\left.\mathrm{cfu} / \mathrm{mL}\right)$ obtained from the final model.

${ }^{3}$ Ref. $=$ reference.

respectively (Annual Report 2009; Milk Control Centre Flanders, 2009). Altogether, the results are believed to reflect the $\mathrm{BC}$ and $\mathrm{CC}$ status of typical dairy herds in Flanders and are likely valid for the Flemish dairy situation and herds of other regions and countries with similar management conditions.

The average $\mathrm{BC}$ in our study was slightly lower than the $11.4 \times 10^{3} \mathrm{IBC} / \mathrm{mL}$ found in New York State (van Schaik et al., 2002). The average CC, on the other hand, was almost half of the average $\mathrm{CC}$ of $44 \mathrm{cfu} / \mathrm{mL}$ across several studies (e.g., Elmoslemany et al., 2009b; Pantoja et al., 2011), suggesting better conditions on the Flemish dairy farms compared with the farms included in the other studies (Jayarao and Wolfgang, 2003). As was expected, the average $\mathrm{CC}$ and $\mathrm{BC}$ strongly varied among herds, which are comparable with other studies (Elmoslemany et al., 2009a,b; Pantoja et al., 2011; Mallet et al., 2012).

Several variables reflecting milking, herd health, and dry cow management were significantly associated with either BC or CC, but explained only a small proportion of their total variance. The latter suggests that the bacteriological milk quality and, in particular, the $\mathrm{CC}$ is primarily driven by other management practices than those studied, such as factors related to milking equipment and milk storage, although unknown factors should be suspected as well. Obviously, the fact that several associations were statistically significant in the analyses not necessarily indicates that a causal relation exists (Dohoo et al., 1997). Rather, some associations

Table 7. Cross tabulation of the 2 independent variables milking machine type and milking parlor type

\begin{tabular}{lrrrrr}
\hline & \multicolumn{5}{c}{ Milking machine type } \\
\cline { 2 - 5 } & $\begin{array}{l}\text { Low } \\
\text { line }\end{array}$ & $\begin{array}{c}\text { High } \\
\text { line }\end{array}$ & $\begin{array}{c}\text { With } \\
\text { glass jar }\end{array}$ & $\begin{array}{c}\text { Automatic } \\
\text { milking system }\end{array}$ & Total \\
\hline Milking parlor type & 116 & 4 & 25 & 0 & 145 \\
Fishbone & 48 & 3 & 2 & 0 & 53 \\
Tandem & 18 & 0 & 1 & 0 & 19 \\
Rotary & 6 & 0 & 0 & 0 & 6 \\
Side-by-side & 0 & 0 & 0 & 13 & 13 \\
Automatic milking system & 0 & 17 & 0 & 13 & 253 \\
Tie-stall & 188 & 24 & 28 & & 17 \\
Total & & & & & \\
\hline
\end{tabular}




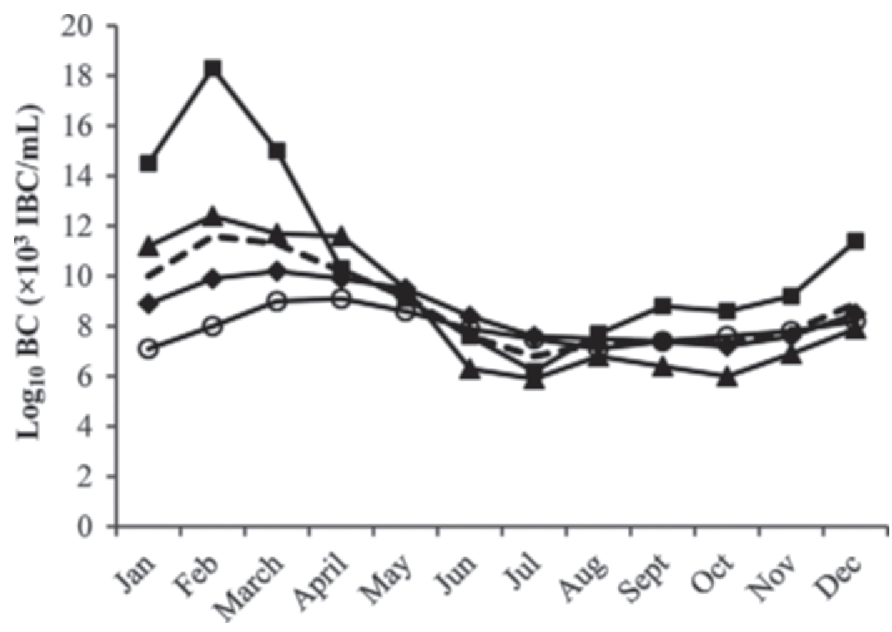

Figure 2. Back-transformed LSM of logarithm of bacterial count $\left[\mathrm{BC} ; \times 10^{3}\right.$ individual $\left.\mathrm{BC}(\mathrm{IBC}) / \mathrm{mL}\right]$ throughout the year $\left(--\right.$ - $^{-}$for herds where the cubicles were cleaned once per week $(\mathbf{\square})$, once per day $(\boldsymbol{\Lambda})$, twice per day $(\bullet)$, or more than 2 times per day $(\bigcirc)$.

need confirmation, whereas others, such as the association between prepartum antibiotic treatment in heifers and $\mathrm{CC}$ as well as the negative association between feeding diets supplemented with minerals to the dry cows and $\mathrm{BC}$, generate new hypotheses on controlling $\mathrm{BC}$ and $\mathrm{CC}$ that should be tested.

Bacterial counts and CC changed over time. Bacterial counts were highest during the winter and spring months, whereas CC followed the opposite pattern. In other studies conducted in the Balearic Islands, Chile, and Prince Edward Island, both BC and CC were highest in summer (Soler et al., 1995; van Schaik et al., 2002; Elmoslemany et al., 2010). The discrepancy between our results and those reported by others can yet not be fully explained, but might be related to the temperate maritime climate in Belgium with ample rainfall

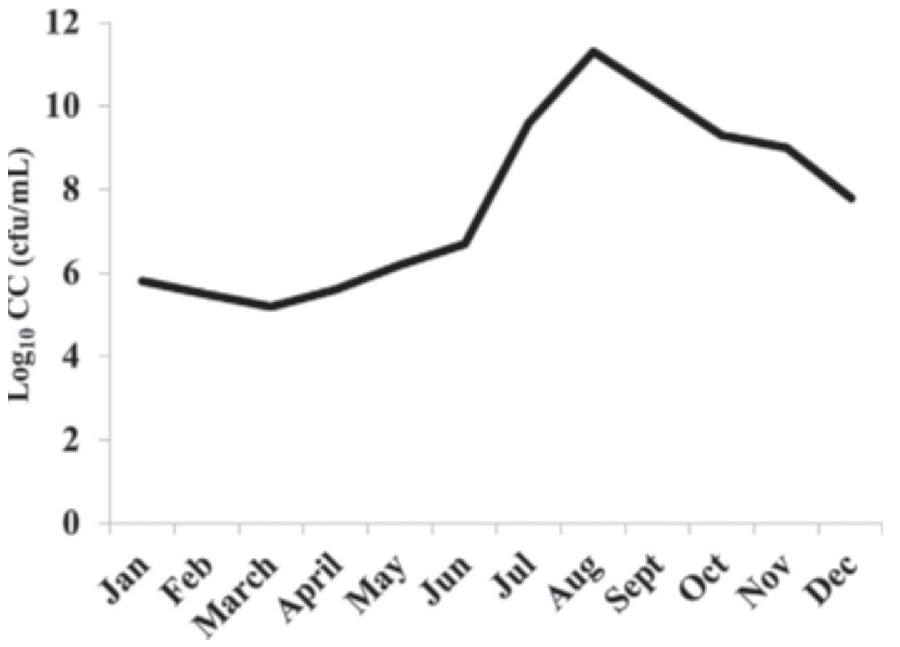

Figure 3. Back-transformed LSM of logarithm of coliform count (CC; cfu $/ \mathrm{mL}$ ) throughout the year.

all year round. The fact that cows on Flemish dairy farms are in confined housing from October to May might expose the udder and teats under the rather mild and humid weather conditions to high bacterial levels, increasing the risk for contamination of the udder and teats in the winter and spring months. The opposite pattern of $\mathrm{CC}$ compared with $\mathrm{BC}$ indicates that both are partly determined by other factors. Coliforms only start to grow and multiply when the ambient temperature exceeds $10^{\circ} \mathrm{C}$ (Naemura and Seidler, 1978). Accumulation of soil from the teats and udders somewhere in the milking equipment will, therefore, have a larger effect on $\mathrm{CC}$ in the summer than in the winter.

The dose-response relationship of frequency of cleaning of the housing on BC between January and March corresponded well with the data published by Kelly et al. (2009). Frequency of bedding change has been asso-

Table 8. Variance components at each level of the null and final multivariable models for logarithm of bacterial count $(\mathrm{BC})$ and logarithm of coliform count (CC), respectively

\begin{tabular}{|c|c|c|c|c|c|c|}
\hline \multirow[b]{2}{*}{ Data hierarchy } & \multicolumn{3}{|c|}{ Null model ${ }^{1}$} & \multicolumn{3}{|c|}{ Final model $^{2}$} \\
\hline & Estimate & $\mathrm{SE}^{3}$ & $\%^{4}$ & Estimate & $\mathrm{SE}^{3}$ & $\%^{4}$ \\
\hline \multicolumn{7}{|l|}{$\mathrm{BC}$} \\
\hline Herd level & 0.798 & 0.010 & 93.6 & 0.767 & 0.011 & 94.3 \\
\hline Observation level & 0.054 & 0.003 & 6.4 & 0.046 & 0.002 & 5.7 \\
\hline Total variance & 0.852 & - & 100 & 0.813 & - & 100 \\
\hline \multicolumn{7}{|l|}{$\mathrm{CC}$} \\
\hline Herd level & 0.719 & 0.012 & 68.1 & 0.709 & 0.013 & 68.6 \\
\hline Observation level & 0.337 & 0.014 & 31.9 & 0.325 & 0.014 & 31.4 \\
\hline Total variance & 1.056 & - & 100.0 & 1.034 & - & 100.0 \\
\hline
\end{tabular}

${ }^{1}$ Model containing only month of observation as fixed effect to take the longitudinal nature of the data set into account.

${ }^{2}$ Model containing all fixed effects as presented in Tables 5 and 6 .

${ }^{3}$ Standard error of the variance estimate of the parameter.

${ }^{4}$ Variance proportion explained at the level of the data hierarchy. 
ciated with the cleanliness of the udder and teats and, thus, the exposure of teats to bacteria (Ward et al., 2002). Also, dirty teats increase the risk of elevated BC (Elmoslemany et al., 2009a). Keeping in mind the confinement housing and the mild and wet Belgian weather conditions in wintertime, farmers should, in particular during those months, put more effort in keeping the housing of the lactating cows clean.

The higher $\mathrm{BC}$ and $\mathrm{CC}$ levels on farms equipped with an automatic milking system are complementary to the increasing bulk milk BC levels observed on farms switching from conventional to automatic milking (Rasmussen et al., 2002; de Koning et al., 2003). The increase in BC shortly after introduction of the automatic milking system has been suggested to partly originate from contamination of milk from the teat surfaces and partly from the inappropriate cleaning of the milking equipment and cooling of the milk (Rasmussen et al., 2002). The CC was also affected by the type of milking machine. Higher $\mathrm{CC}$ were observed in milking parlors with a high-pipeline setup compared with those with a low-pipeline setup or reservoir (Reinemann et al., 2003). A common denominator among the studies that have already been performed is the overriding importance of proper cleaning and sanitation of the milking system in producing high-quality milk (Elmoslemany et al., 2009a; Pantoja et al., 2011). The cleaning and sanitation of the pipelines in stalls with a high-pipeline setup are more often lacking than in other milking systems, likely due to the higher risk for accumulation of milk fat and drying of milk in the high-pipeline setup and, in particular, in the cool line at the high end of the system (Reinemann et al., 2003).

Individual $\mathrm{BC}$ was affected by premilking teat cleaning practices, which was not that unexpected, as Elmoslemany et al. (2009a) reported that the risk of having high BC increased by 5.3 for each unit increase in the teat-end cleanliness before the milking unit was attached. In our study, a wet teat preparation followed by dry wiping was more strongly associated with lower BC than dry wiping with a paper towel alone, corresponding well with the results of Kelly et al. (2009). Still, in almost $25 \%$ of the cases, the wet teat preparation consisted of premilking teat disinfection, which was associated with lower BC as well, which is obviously positive. The latter finding corresponds well to the numerous studies that showed a strong reducing effect of premilking teat disinfection on the teat microbial load (e.g., Galton et al., 1986; Magnusson et al., 2006; Gibson et al., 2008).

A negative relationship was found between the presence of automatic removal and $\mathrm{BC}$, which is in accordance with the results reported by Kelly et al. (2009). This finding might be related to the increased risk for teat end callosity and hyperkeratosis in the case of manual cluster removal. Teats with a highly calloused teat end have an increased load of environmental pathogens (Paduch et al., 2012). Also, teats with a distinct callosity ring are most likely less effectively cleaned during premilking teat preparation, leaving more bacteria on the teat end when the milking cluster is attached (Hovinen et al., 2005). Although few peerreviewed publications are available on the risk factors associated with teat-end callosity, it is reasonable to accept that manual cluster removal might more often lead to overmilking compared with automatic cluster removal, thereby compromising the teat-end quality (Rasmussen et al., 1991; Gleeson et al., 2003).

\section{CONCLUSIONS}

Multivariable, multilevel regression analysis revealed several management practices associated with either BC or CC. Increasing the cleaning frequency of the housing during wintertime under the Belgian weather conditions and implementing premilking teat disinfection by either dipping or spraying the teats before attaching the milking unit will likely result in lower $\mathrm{BC}$ values. The variation in both $\mathrm{BC}$ and $\mathrm{CC}$ seems to be mainly determined by differences in management between the herds, as most variation in both parameters resided at the herd rather than at the observation level. As only a small proportion of the total variance was explained by the management practices included in our study, bacteriological milk quality seems to be primarily driven by other factors than the ones included in this study.

\section{ACKNOWLEDGMENTS}

The authors thank the Milk Control Centre Flanders (Belgium) for providing us with the $\mathrm{BC}$ and $\mathrm{CC}$ recordings. All farmers that cooperated by completing the online questionnaire are gratefully acknowledged. Thanks must go to MSD Animal Health Belgium (ex. Intervet Belgium, Brussels, Belgium) for supporting this study.

\section{REFERENCES}

Barbano, D. M., Y. Ma, and M. V. Santos. 2006. Influence of raw milk quality on fluid milk shelf life. J. Dairy Sci. 89(Suppl.1):E15-E19.

Barkema, H. W., Y. H. Schukken, T. J. G. M. Lam, M. L. Beiboer, G. Benedictus, and A. Brand. 1998. Management practices associated with low, medium, and high somatic cell counts in bulk milk. J. Dairy Sci. 81:1917-1927.

Berry, D. P., B. O'Brien, E. J. O'Callaghan, K. O. Sullivan, and W. J. Meaney. 2006. Temporal trends in bulk tank somatic cell count and total bacterial count in Irish dairy herds during the past decade. J. Dairy Sci. 89:4083-4093.

Boor, K. J. 2001. Fluid dairy product quality and safety: Looking to the future. J. Dairy Sci. 84:1-11.

de Koning, K., B. Slaghuis, and Y. van der Vorst. 2003. Robotic milking and milk quality: Effects on bacterial count, somatic cell 
counts, freezing point and free fatty acids. Ital. J. Anim. Sci. 2:291-299.

De Vliegher, S., H. Laevens, H. W. Barkema, I. R. Dohoo, H. Stryhn, G. Opsomer, and A. de Kruif. 2004. Management practices and heifer characteristics associated with early lactation somatic cell count of Belgian dairy heifers. J. Dairy Sci. 87:937-947.

Dohoo, I., M. Wayne, and H. Stryhn, editors. 2009. Questionnaire design. Pages 58-72 in Veterinary Epidemiologic Research. 2nd ed. VER Inc., Charlottetown, PE, Canada.

Dohoo, I. R., C. Ducrot, C. Fourichon, A. Donald, and D. Hurnik. 1997. An overview of techniques for dealing with large numbers of independent variables in epidemiologic studies. Prev. Vet. Med. $29: 221-239$.

Elmoslemany, A. M., G. P. Keefe, I. R. Dohoo, and B. M. Jayarao. 2009a. Risk factors for bacteriological quality of bulk tank milk in Prince Edward Island dairy herds. Part 1: Overall risk factors. J. Dairy Sci. 92:2634-2643.

Elmoslemany, A. M., G. P. Keefe, I. R. Dohoo, and B. M. Jayarao. 2009b. Risk factors for bacteriological quality of bulk tank milk in Prince Edward Island dairy herds. Part 2: Bacteria count-specific risk factors. J. Dairy Sci. 92:2644-2652.

Elmoslemany, A. M., G. P. Keefe, I. R. Dohoo, J. J. Wichtel, H. Stryhn, and R. T. Dingwell. 2010. The association between bulk milk analysis for raw milk quality and on-farm management practices. Prev. Vet. Med. 95:32-40.

Galton, D. M., L. G. Petersson, and W. G. Merrill. 1986. Effects of premilking udder preparation practices on bacterial counts in milk and on teats. J. Dairy Sci. 69:260-266.

Gibson, H., L. A. Sinclair, C. M. Brizuela, H. L. Worton, and R. G. Protheroe. 2008. Effectiveness of selected premilking teat-cleaning regimes in reducing teat microbial load on commercial dairy farms. Lett. Appl. Microbiol. 46:295-300.

Gilmour, A., and M. T. Rowe. 1990. Micro-organisms associated with milk. Pages 37-114 in Dairy Microbiology. 1st ed. R. K. Robinson, ed. Elsevier Science Publishers, London, UK.

Gleeson, D. E., E. J. O'Callaghan, and M. Rath. 2003. The effects of genotype, milking time and teat-end vacuum pattern on the severity of teat-end hyperkeratosis. Ir. J. Agric. Food Res. 42:195-203.

Hovinen, M., A.-M. Aisla, and S. Pyörälä. 2005. Visual detection of technical success and effectiveness of teat cleaning in two automatic milking systems. J. Dairy Sci. 88:3354-3362.

Jayarao, B. M., S. R. Pillai, A. A. Sawant, D. R. Wolfgang, and N. V. Hegde. 2004. Guidelines for monitoring bulk tank milk somatic cell and bacterial counts. J. Dairy Sci. 87:3561-3573.

Jayarao, B. M., and D. R. Wolfgang. 2003. Bulk-tank milk analysis. A useful tool for improving milk quality and herd udder health. Vet. Clin. North Am. Food Anim. Pract. 19:75-92.

Kelly, P. T., K. O'Sullivan, D. P. Berry, S. J. More, W. J. Meaney, E. J. O'Callaghan, and B. O'Brien. 2009. Farm management factors associated with bulk tank total bacterial count in Irish dairy herds during 2006/07. Ir. Vet. J. 62:36-42.

Magnusson, M., A. Christiansson, B. Svensson, and C. Kolstrup. 2006. Effect of different premilking manual teat-cleaning methods on bacterial spores in milk. J. Dairy Sci. 89:3866-3875.
Maldonado, G., and S. Greenland. 1993. Simulation study of confounder-selection strategies. Am. J. Epidemiol. 138:923-936.

Mallet, A., M. Gueguen, F. Kauffmann, C. Chesneau, A. Sesboué, and N. Desmasures. 2012. Quantitative and qualitative microbial analysis of raw milk reveals substantial diversity influenced by herd management practices. Int. Dairy J. 27:13-21.

Milk Control Centre Flanders. 2009. Annual Report. Pages 19-20. Milk Control Centre Flanders, Lier, Belgium.

Murphy, S. C. 1997. Raw milk bacteria tests: Standard plate count, preliminary incubation count, lab, pasteurization count and coliform count. What do they mean for your farm? Pages 34-41 in Natl. Mastitis Council. Reg. Mtg. Proc., Syracuse, NY. Natl. Mastitis Council Inc., Madison, WI.

Murphy, S. C., and K. J. Boor. 2000. Troubleshooting sources and causes of high bacteria counts in raw milk. Dairy Food Environ. Sanit. 20:606-611.

Naemura, L. G., and R. J. Seidler. 1978. Significance of low-temperature growth associated with the fecal coliform response, indole production, and pectin liquefaction in Klebsiella. Appl. Environ. Microbiol. 35:392-396.

Paduch, J.-H., E. Mohr, and V. Krömker. 2012. The association between teat end hyperkeratosis and teat canal microbial load in lactating dairy cattle. Vet. Microbiol. 158:353-359.

Pantoja, J. C. F., D. J. Reinemann, and P. L. Ruegg. 2011. Factors associated with coliform count in unpasteurized bulk milk. J. Dairy Sci. 94:2680-2691.

Rasmussen, M. D., M. Bjerring, P. Justesen, and L. Jepsen. 2002. Milk quality on Danish farms with automatic milking systems. J. Dairy Sci. 85:2869-2878.

Rasmussen, M. D., D. M. Galton, and L. G. Petersson. 1991. Effects of premilking teat preparation on spores of anaerobes, bacteria, and iodine residues in milk. J. Dairy Sci. 74:2472-2478.

Reinemann, D. J., G. M. V. H. Wolters, P. Billon, O. Lind, and M. D. Rasmussen. 2003. Review of practices for cleaning and sanitation of milking machines. Bull. 381. Int. Dairy Fed., Brussels, Belgium.

Soler, A.. C. Ponsell, M. De Paz, and M. Nuñez. 1995. The microbiological quality of milk produced in the Balearic Islands. Int. Dairy J. 5:69-74.

van Schaik, G., L. E. Green, D. Guzman, E. Esparza, and N. Tadich. 2005. Risk factors for bulk milk somatic cell counts and total bacterial counts in smallholder dairy farms in the 10th region of Chile. Prev. Vet. Med. 67:1-17.

van Schaik, G., M. Lotem, and Y. H. Schukken. 2002. Trends in somatic cell counts, bacterial counts, and antibiotic residue violations in New York State during 1999-2000. J. Dairy Sci. 85:782-789.

Ward, W. R., J. W. Hughes, W. B. Faull, P. J. Cripps, J. P. Sutherland, and J. E. Sutherst. 2002. Observational study of temperature moisture, $\mathrm{pH}$ and bacteria in straw bedding, and faecal consistency, cleanliness and mastitis in cows in four dairy herds. Vet. Rec. 151:199-206.

Zadoks, R. N., R. N. Gonzales, K. J. Boor, and Y. H. Schukken. 2004. Mastitis-causing streptococci are important contributors to bacterial count in raw bulk tank milk. J. Food Prot. 67:2644-2650. 